Jurnal Ilmu dan Teknologi Kesehatan

Vol 8, No 1, September 2020,

ISSN: 2338-9095 (Print)

ISSN: 2338-9109 (online)

\title{
Double Threat of Indonesian Maternal Health During The Pandemic of Covid-19
}

\author{
Astri Nurdiana, Uway Wariah, Irma Yanti \\ Universitas Singaperbangsa Karawang, Indonesia \\ Email: astri.nurdiana@fikes.unsika.ac.id
}

\author{
Article history \\ Posted, Aug 5th, 2020 \\ Reviewed, Sept 10th, 2020 \\ Received, Sept 27th, 2020
}

\begin{abstract}
The high maternal mortality rate is a complex health challenge reported in Indonesia long before the Covid-19 pandemic. However, the challenge of reducing the number of deaths has increased with the pandemic. This research was a descriptive-analytic study using a retrospective cohort design. The population in this survey was 96 mothers from 30 districts in Karawang who went through pregnancy, postpartum, newborn, and family planning experiences between February-May 2020. Therefore, data were collected through virtual interviews with the use of a questionnaire as the research instrument. The highest score was far below 77, with a value 66 and 45.99 average, as shown in the result. The bivariate analysis also showed the influence of participants' last education on the new normal adaptation score with a P-value of 0.006. However, terminating the transmission of the Covid-19 virus in Karawang regency is focused not only on the educational efforts of the health workers but also on enhancing people's self-awareness about the necessity of personal hygiene and hand hygiene, and prenatal consultation.
\end{abstract}

Keywords: Covid-19; Indonesia; Karawang; maternal; pandemic

\begin{abstract}
ABSTRAK
Jauh sebelum terjadinya pandemik Covid-19 Indonesia telah menghadapi permasalahan kesehatan yang cukup rumit, yaitu tingginya angka kematian maternal. Tantangan untuk menurunkan kasus kematian maternal semakin meningkat di tengah terjadinya pandemik Covid19. Penelitian ini bertujuan untuk menggali perilaku ibu mengenai pencegahan transmisi melalui adaptasi kebiasaan baru di masa kehamilan, persalinan, nifas, bayi baru lahir dan keluarga berencana. Penelitian ini merupakan penelitian deskriptif analitik menggunakan desain kohort retrospektif, populasi dalam penelitian ini merupakan seluruh ibu yang terlibat dalam studi kasus mahasiswa kebidanan Unsika yaitu sebanyak 96 ibu yang berasal dari 30 Kecamatan di
\end{abstract}


Kabupaten Karawang. Kriteria inklusi dalam penelitian ini adalah seluruh ibu yang sudah melalui masa kehamilan, persalinan, nifas dan KB selama periode Februari-Mei 2020. Instrumen penelitian menggunakan kuesioner, pengambilan data dilakukan melalui wawancara virtual. Hasil rekapitulasi kuesioner didapatkan bahwa skor tertinggi sebanyak 66 dengan nilai rata-rata 45,99, yang mana angka tersebut berada di bawah skor total yaitu 77, hasil analisis bivariat didapatkan bahwa pendidikan terakhir ibu memperngaruhi skor adaptasi kebiasaan baru dengan nilai $\mathrm{P}$ sebesar 0,006. Penghentian transmisi virus Covid-19 di Kabupaten Karawang tidaklah hanya terfokus pada upaya edukasi oleh tenaga kesehatan, namun kesadaran dari diri sendiri untuk selalu menjaga higienitas tubuh serta lingkungan sekitar.

Kata Kunci: Covid-19; Indonesia; Karawang; maternal; pandemi

\section{INTRODUCTION}

There was a worldwide outbreak of acute respiratory syndrome at the end of 2020. It was the most significant plague disaster in the last decade, resulting from the Novel Coronavirus SARS-Cov2, commonly known as Covid-19. However, there are no signs to indicate Indonesia's possible end after six months, with over 30 million people globally and 296,513 Indonesian sufferers, as of September 2020 (Worldometer, 2020). The first Covid-19 case in Indonesia was discovered in Depok City then spread to Jakarta and the surrounding areas, including Karawang Regency, where there were 522 cases based on Sept 17th, 2020 data. It implies that 21 out of 30 Districts in this region became the transmitted area.

Furthermore, various efforts have been made by the government to overcome this problem. These include closing all air and water entry routes, implementing large-scale social restriction (PSBB) policies, altering athletes' houses into emergency hospitals (RS) to handle the Covid-19 cases, rapid and mass swab tests performance, closure of various entertainment and recreational facilities. However, this pandemic has tended to fluctuate and has not shown any decline (Ministry of National Affairs, 2020). Also, Indonesia had encountered numerous complex health problems long before the Covid-19 pandemic. It includes high maternal mortality, which has become the highlight of international communities. The World Health Organization (WHO) data from 2015 states that most deaths occur in low-income countries. Furthermore, up to $22 \%$ of deaths in the world occur in Southeast Asia, where Indonesia is in third place (WHO et al., 2015).

The Indonesian health profile reports 4,226 maternal mortality in Indonesia by 2019 , with 700 deaths, with the highest in West 
Java. Meanwhile, there has been no significant decrease, with 46 and 45 cases in 2018 and 2019, respectively, in Karawang Regency. The challenge to reduce the maternal mortality cases has increased amid the Covid-19 pandemic. However maternal health sector needs extra attention during the pandemic of Covid-19 to prevent multiple aspects that could treat the mother and baby well-being. Therefore, the study of Covid-19 is currently very crucial. This study focuses on exploring mothers' responses regarding transmission prevention through the adaptation of new normal habits related to pregnancy, childbirth, postpartum, and family planning.

\section{METHOD}

This is a descriptive-analytic study using a retrospective cohort design. The population involved 110 mothers 30 districts in Karawang Regency, where the sample selection was utilized randomly based on the local midwife database. The inclusion criteria in this study involved all mothers in areas covered by the internet network and had experienced pregnancy, childbirth, postpartum during the Covid-19 pandemic period between February-May 2020. Furthermore, after the identification results were obtained from 96 mothers, 14 were excluded due to internet inaccessibility during the interview from April-June 2020. Also, there were modifications in data collection due to this pandemic, including virtual interviews by WhatsApp video calling. The research instruments used a questionnaire compiled from various references, including Hill (2020) (Boelig et al., 2020), Rasmussen and Jamieson (2020), and the Indonesia Ministry of Health (2020). Furthermore, 16 questions regarding the new normal adaptation related to the Covid-19 virus transmission prevention were compiled through general prophylaxis, including pregnancy inhibition, childbirth, newborns, and postpartum, using the Likert scale. It was based on the results of the literature review.

The research questionnaire has been through the reliability test process with a Cronbach's Alpha score of 0.73 , while the outcome of the validity trial obtained an $r$ count of greater than 0.3 . This survey was valid and reliable for use as an instrument based on the test results. Furthermore, all questionnaire questions were embedded in a google form and used as an interview guide. The interviewers selected 20 students 
inclined to be involved in this research activity. Subsequently, data collection results were given a score according to the Likert scale score, including 1, 2, 3, 4, and 5 for the answer never, rarely, sometimes, often, and persistent, respectively. The recapitulation of the survey score and system is listed in the supplement file. Subsequently, data acquired from the interviews were analyzed with the aid of a statistical program. The first stage, descriptive data analysis, entailed calculating all new normal adaptation scores and generated a maximum total answer of 77. Furthermore, a bivariate evaluation of the zone variables, education, age, and marks was carried out using the unpaired TTest.

\section{RESULTS AND DISCUSSION}

This study's participants were determined by purposive sampling as women who had passed the pregnancy, childbirth, postpartum, and family planning periods during the pandemic in April and May 2020. Based on these inclusion criteria, 96 mothers were recruited.

The respondents were spread across five regions according to the Covid-19 zoning, with the most populated being the yellow $(33.3 \%)$, black $(27.1 \%)$, and green $(25 \%)$ zones. Table 1 indicates the participants' most recent education was elementary and junior high school (63.5\%), and $76 \%$ of the respondents were $\leq 30$ years old

Table 1. Respondents Characteristics of the Research

\begin{tabular}{lcc}
\hline \multicolumn{1}{c}{ Characteristics } & n (\%) & P-Value \\
\hline Zones & $26(25 \%)$ & \\
$\quad$ Green & $9(9,4 \%)$ & $>0,05$ \\
Blue & $31(32,3 \%)$ & \\
$\quad$ Yellow & $5(5,2 \%)$ & \\
$\quad$ Red & $19(27,1 \%)$ & \\
$\quad$ Black & $61(63,5 \%)$ & $>0,05$ \\
\hline Education & $35(36,5 \%)$ & \\
$\quad$ Elementary School / Junior High School & $73(76,0 \%)$ & $>0,05$ \\
$\quad$ Senior High School/Colleges & $23(24,0 \%)$ & \\
\hline Age & & \\
$\quad \leq 30$ years & & \\
$\quad>30$ years &
\end{tabular}

All characteristic data are homogeneous with $\mathrm{P}$ value $>0.05$. 


\section{General Prevention}

Table 2. New Normal Adaptation of General Prevention

\begin{tabular}{|c|c|c|c|c|c|c|}
\hline & & 1 & 2 & 3 & 4 & 5 \\
\hline No & Activities & Never & Rarely & Sometimes & Often & $\begin{array}{l}\text { Very } \\
\text { Often }\end{array}$ \\
\hline 1. & $\begin{array}{l}\text { Washing hands with soap and running } \\
\text { water for at least } 20 \text { seconds or use an } \\
\text { alcohol-based hand sanitizer containing at } \\
\text { least } 70 \% \text { alcohol if soap and water are not } \\
\text { available }\end{array}$ & $0 \%$ & $14,6 \%$ & $33,3 \%$ & $47,9 \%$ & $4,2 \%$ \\
\hline 2. & $\begin{array}{l}\text { I do not touch the eyes, nose, and mouth } \\
\text { with unwashed hands. }\end{array}$ & $6,3 \%$ & $17,7 \%$ & $61,5 \%$ & $13,5 \%$ & $1 \%$ \\
\hline 3. & $\begin{array}{l}\text { Avoid contact with sick people, including } \\
\text { the own family member }\end{array}$ & $5,2 \%$ & $18,8 \%$ & $37,5 \%$ & $32,3 \%$ & $6,3 \%$ \\
\hline 4. & $\begin{array}{l}\text { Cover mouth and nose when coughing or } \\
\text { sneezing with a tissue }\end{array}$ & $1 \%$ & $12,5 \%$ & $30,2 \%$ & 43,8 & $12,5 \%$ \\
\hline 5. & Throw away dirty tissue in its place & $1 \%$ & $3,1 \%$ & $16,7 \%$ & $59,4 \%$ & $19,8 \%$ \\
\hline 6. & Using a mask when outdoors & $1 \%$ & $6,3 \%$ & $17,7 \%$ & $47,9 \%$ & $27,1 \%$ \\
\hline 7. & $\begin{array}{l}\text { The closest family used a mask when } \\
\text { accompanying me }\end{array}$ & $11,5 \%$ & $25,0 \%$ & $45,8 \%$ & $14,6 \%$ & $3,1 \%$ \\
\hline 8. & Seeking Information about Covid-19 & $0 \%$ & $14,6 \%$ & $44,8 \%$ & $33,3 \%$ & $7,3 \%$ \\
\hline 9. & $\begin{array}{l}\text { Conducting online consultation with health } \\
\text { workers }\end{array}$ & $26,0 \%$ & $14,6 \%$ & $32,3 \%$ & $22,9 \%$ & $4,2 \%$ \\
\hline
\end{tabular}

Table 2 shows the Likert rating result on the mothers' responses to nine questions concerning the general prevention adaptation towards Covid-19. These answers were rated either as never, rarely, sometimes, often, or very often. Also, the subsequent analysis indicated the majority of respondents often washed their hands with soap (70\%), alcohol-based sanitizer (47.9\%), covered their mouths and nose with a tissue while coughing or sneezing (43.8\%), disposed of dirty tissues in its place $(59.4 \%)$ and made use of a mask while outdoors (47.9\%). Meanwhile, others avoided touching their eyes, nose, mouth with unwashed hands (61.5\%), as well as contact with sick people, including family members (37.5\%) and had even closest relatives use a mask while being accompanied (45.8\%). Besides, some equipped themselves with knowledge of the virus $(44.8 \%)$, while 
$32.3 \%$ of respondents stated they sometimes consulted with health workers online.

Some respondents admitted they rarely washed or sanitized their hands. The use of alcohol-based sanitizers was the easiest and most effective step transmission prevention step (Kampf et al., 2020). Also, Kampf et al., (2020) reported tests had been carried out using six types of biocidal agents that can kill the Human Corona Virus/Covid-19 affixed to the surface of iron, glass, and plastic reported in the article published on Jan 31st, 2020. These are 70\% Ethanol/alcohol, $\quad 0.04 \%$ Benzalkhoniumchloride, $5 \% \quad$ Sodium Hypochlorite o, 1\% Sodium Hypochlorite o, $0.01 \%$ Sodium Hypochlorite, and 2\% Glutardialdehyde solutions. The results indicated the micro-organism survives on iron, glass, and plastic surfaces for up to 9 days, but is efficiently inactivated by disinfection with a $62-71 \%$ alcohol mixture (Kampf et al., 2020).

Therefore, negligence in handwashing is a detrimental habit, especially when a mother has touched an inanimate surface affixed with the virus. Covid-19 causes acute respiratory infection syndrome, and the incubation period ranges from 2 to 14 days. Furthermore, the symptoms include mild to severe breathing problems, body temperature above $37.8^{\circ} \mathrm{C}$, fatigue, dry cough, shortness of breath, myalgia, diarrhea, and nausea. However, patients heal without specific treatment (Hill, 2020; Liberati et al., 2020; Shi et al., 2020; Sohrabi et al., 2020; Zhai et al., 2020).

Other preventive measures adopted include avoiding contact with sick people, covering the nose when coughing or sneezing, and disposing of dirty tissue properly. This disease is transmitted through saliva and other bodily fluids. Therefore, maintaining a distance of 1-2 meters from others, not touching the face, covering the mouth and nose as one sneeze, staying indoors when unwell, avoiding smoking, delaying traveling and gathering groups as well as complying with related government regulations are effective methods to curb transmission (Jernigan, 2020; Sohrabi et al., 2020).

\section{Adaptation for Pregnancy, Childbirth, Postpartum, Newborn and Family Planning}

There were three questions covering adjustments during pregnancy, three regarding labor, postpartum, and newborns, with one related to family planning, and the results are enumerated in tables 3, 4, and 5. 
The details listed in table 3 specified three inquiries concerning the changes observed during pregnancy. From the results displayed, $58.3 \%$ had never postponed antenatal care during the pandemic. The majority of respondents had made appointments for well-being assessments (30, 2\%), and as many as $39.6 \%$ often experienced fetal movements alone.

Table 3. New Normal Adaptation during Pregnancy

\begin{tabular}{|c|c|c|c|c|c|c|}
\hline & & 1 & 2 & 3 & 4 & 5 \\
\hline No & Activities & Never & Rarely & Sometimes & Often & $\begin{array}{l}\text { Very } \\
\text { Often }\end{array}$ \\
\hline 1. & $\begin{array}{l}\text { Postponing pregnancy care during the } \\
\text { COVID pandemic }\end{array}$ & $58,3 \%$ & $6,3 \%$ & $18,8 \%$ & $15,6 \%$ & $1 \%$ \\
\hline 2. & $\begin{array}{l}\text { The mother made an appointment with the } \\
\text { health worker when she wanted to check } \\
\text { her condition }\end{array}$ & $25 \%$ & $12,5 \%$ & $30,2 \%$ & $26,0 \%$ & $6,3 \%$ \\
\hline 3. & $\begin{array}{l}\text { During the pregnancy, the mother } \\
\text { calculates the fetal movements herself }\end{array}$ & $9,4 \%$ & $13,5 \%$ & $27,1 \%$ & $39,6 \%$ & $10,4 \%$ \\
\hline
\end{tabular}

Table 4 comprised three questions involving the acclimatization of new mothers to childbirth, postpartum, and Family Planning. Consequently, $51 \%$ of the candidates confirmed the lack of use of masks when in close proximities or breastfeeding the babies, $42.7 \%$ agreed to frequent hand washes before touching the child. In comparison, $35.4 \%$ also performed this activity before breastfeeding.

Table 4. New Normal Adaptation during Childbirth, Postpartum, and Newborn

\begin{tabular}{llccccc}
\hline No & \multicolumn{1}{c}{ Activities } & $\begin{array}{c}1 \\
\text { Never }\end{array}$ & $\begin{array}{c}2 \\
\text { Rarely }\end{array}$ & $\begin{array}{c}3 \\
\text { Sometimes }\end{array}$ & $\begin{array}{c}4 \\
\text { Often }\end{array}$ & $\begin{array}{c}5 \\
\text { Very } \\
\text { Often }\end{array}$ \\
\hline 1. $\quad \begin{array}{l}\text { The mother wears masks when close to babies or } \\
\text { breastfeeding }\end{array}$ & $51,0 \%$ & $22,9 \%$ & $22,9 \%$ & $3,1 \%$ & $0 \%$ \\
2. $\quad \begin{array}{l}\text { Mother washes their hands before touching babies } \\
\text { 3. } \quad \text { Mother washes their hands before breastfeeding }\end{array}$ & $11 \%$ & $5,2 \%$ & $32,3 \%$ & $42,7 \%$ & $18,8 \%$ \\
\hline
\end{tabular}


Table 5 presented the contraception types utilized by mothers during the Covid-19 pandemic, and the interview demonstrated the dominant use of short-term birth control methods with a frequency of $95.8 \%$.
Moreover, the questionnaire recapitulation results discovered the highest score of 66 and the lowest 29, with a mean value of 45.99 and a median of 45.

Table 5. New Normal Adaptation of Using Contraception

\begin{tabular}{lc}
\hline \multicolumn{1}{c}{ The Contraception Types } & $\boldsymbol{\%}$ \\
\hline short-term birth control methods & $95,8 \%$ \\
long-term birth control methods & $4,2 \%$ \\
\hline
\end{tabular}

Based on the interviews, some respondents do not always use masks outside the house or insist on relatives wearing masks around them. Liu et al. (2020) reported on the risk of pregnant women towards contracting the virus. Also, in some cases, there is an increased tendency of preterm delivery and distress in infants, although this effect has not been proven to be directly instigated by the virus. Furthermore, Covid-19 is known to alter the immune response and subsequently influence mothers' and babies' well-being. Rasmussen and Jamieson (2020) showed that the fatality rate of the Middle East respiratory syndrome for similar viruses in pregnant women is $35-40 \%$. Hence, various adaptations are required to prevent further transmission (Boelig et al., 2020; Renfrew et al., 2020; Glasper, 2020).
Cheng et al. (2020) conducted a study in the Hong Kong Special Administrative Region (HKSAR) to confirm the widespread use of masks in society contributed to the reduced prevalence of Covid-19 by restricting the number of saliva splashes or exposure from the respiratory tract. Besides, medical masks are more effective in preventing infection than cloth masks (MacIntyre et al., 2015; Cheng et al., 2020).

The viral outbreak has created widespread anxiety, stigma against the victims, limitations of human movement in various parts of the world, and, therefore, become a global health system challenge. This condition consequently encourages the various authorized parties to maintain the quality of health services, and guidelines have been published both at the international and national levels to this effect. 
The World Health Organization (WHO) issued a handbook titled Maintaining essential health services: operational guidance for the COVID-19 context on Jun 1st, 2020. This guide comprised rules and strategies for the Sustainability of Sexual, Reproductive, Maternal, Neonatal, Child, and Youth (SRMNAR) services. It encompassed several details about the efforts exerted by health professionals to promote the provision of excellent medical attention during the pandemic (World Health Organization, 2020). Moreover, The World Health Organization (2020) stated the need for all countries to competently determine the priority hierarchy in the delivery of healthcare, including SRMNAR and other high-risk groups (World Health Organization, 2020).

Furthermore, in the pregnancy care order, the WHO recommended health care facilities to be capable of identifying unsafe pregnancies and modifying agendas and reschedule appointments before visitations to decrease congestion while maintaining a physical distance. This procedure was to be enabled by the replacement of ANC (Antenatal Care) with home visits or remote consultation and counseling to reduce mothers' exposure, alongside a focus on high-risk and half-term pregnancies, and to also ensure the accompaniment of these sectors by adequate infection prevention measures. Also, the Ministry of Health advised mothers to continually use the $\mathrm{MCH}$ (Maternal and Child Healthy) to ensure the source of information and education and consultation. Also, the families were expected to actively monitor pregnancy danger signs, an illustration being the ability of the mother to ensure the movement of the fetus independently at about 20 weeks, alongside the commencement of the estimation to monitor pregnancy danger signs actively of Health of Indonesia, 2020; World Health Organization Indonesia, 2020). Furthermore, Sari et al. (2020) conducted a study on Indonesians' knowledge and attitudes concerning the pandemic, and out of the 201 respondents, 98\% were determined to have good knowledge, while $96 \%$ demonstrated the right attitude.

The attitude statements explored through interviews with 96 mothers postpartum produced a maximum score of 66 with an average value of 45.99 , a figure far below the total grade of 77 . It consequently 
73 Jurnal Ilmu dan Teknologi Kesehatan, Vol. 8, Nomor 1, September 2020, hlm:64-79

represented a significant discrepancy between the results of this research and the study by Sari et al. (2020). Also, the increasing incidence of Covid-19 was accompanied by various innovations in health services. Therefore, a virtual facility in the form of telemedicine was recommended by the Indonesian Ministry of Health. Telemedicine refers to the provision of remote health services by professionals through the use of information and communication technology, including the exchange of diagnostic facts, prevention, and treatment of disease and injury, research and evaluation, as well as sustainable education of medical service providers, for the improvement of individual and community health (Ministry of Health of the Republic of Indonesia, 2019).

Furthermore, the resources' additional benefits include the conservation of medical costs, conveyance of disease complaints only by teleconsultations. It allows for proper management of challenges without the need for referrals and possible encouragement of collaboration among health workers regarding patient illnesses, consequently promoting the swift resolution of these cases. Moreover, this service has numerous applications as a means of care and direct monitoring of patients to minimize medical personnel exposure. Also, there has been applied in special consultations, especially when workers are in high demand and on the instance of the Covid-19 pandemic (Doshi et al., 2020). Besides, the WHO proposed the performance of Covid-19 screening on birth attendants, as skin-to-skin contact between the mother and child and the early initiation of breastfeeding were yet to occur. Similarly, the health ministry included face shields as an alternative for the prevention of the transmission of this virus in neonates (Ministry of Health of Indonesia, 2020; World Health Organization Indonesia, 2020).

Finally, further recommendations by the WHO in postpartum care settings include the prioritization of first contact (within 24 hours of labor) with appropriate infection prevention procedures, as well as the replacement of subsequent contacts with home visits and remote consultations and therapies in situations devoid of risk. Also, the Ministry of Health advised post-delivery family planning methods to be continually implemented by the use of long-term contraceptive methods including intrauterine devices (IUDs), implants, male operative 
methods (MOP) or female operative methods (MOW) (Ministry of Health of Indonesia, 2020; World Health Organization Indonesia, 2020). Also, efforts are being made to prevent the transmission of Covid19 in newborns and breastfeeding mothers. It is because babies of mothers assumed to not be amongst those monitored (ODP), or under surveillance (PDP) or confirmed with a positive diagnosis are mandated to receive essential neonatal services. However, neonate appointments to health care facilities are only performed on the first visits. In contrast, the second and third are possibly carried out by home visits or virtual monitoring (Ministry of Health of Indonesia, 2020).

Also, health workers in nursing care services are always expected to provide breastfeeding counseling, emphasizing the tendency for transmission between mother and baby during close contact. Moreover, direct breastfeeding only allows mothers with normal Covid-19 screening results or those in the ODP category. Meanwhile, mothers demonstrating PDP or possessing a confirmed status are expected to breastfeed indirectly or explore the use of expressed breast milk. Furthermore, it is essential to always be aware of personal hygiene and breastfeeding tools while using this technique. It includes the practice of regular handwashing while touching babies, breasts, breastfeeding equipment, and adopting the use of a face mask (Ministry of Health of Indonesia, 2020).

\section{The Effect of Zone, Age, and Education on the New Normal Adaptation Score}

A total of 3 respondents' variable characteristics were observed in this study, including zone, age, and education. The data normality test results with the new normal adaptation score obtained a significance value of $\mathrm{P}>0.05$ for all variables. They thus concluded to be homogeneous and normally distributed. 
Table 6. The Effect of Zone, Age and Education Variable against the New Normal Adaptation Score

\begin{tabular}{lcc}
\multicolumn{1}{c}{ Variables } & Mean & P-value* \\
\hline The score of the Green/blue/orange zone & 46,06 & 0,89 \\
The score of Black/red zone & 45,84 & \\
& & 0,242 \\
The Score at Age $\leq 30$ years & 44,49 & \\
The Score at Age> 30 years & 44,39 & 0,006 \\
The Score of Elementary School / Junior High & 44,43 & \\
School & 48,71 & \\
The Score of Senior High School/Colleges &
\end{tabular}

The hypothesis testing adopted to determine the effect of the zone, age, and respondents' last education on the new normal adaptation score was carried out using the unpaired Ttest. Table 6 shows the test results indicating the effect of the mother's last education on a new normal adaptation score with a P-value of 0.006 , while the zone and age had no impact.

The West Java Province Covid-19 Acceleration Task Force further divided the Covid-19 zoning at the village level into six criteria. These include the light green zone indicating low-risk areas with population density $<2,750$ people/km2, while the green represents a density of $\geq 2,750$ people / $\mathrm{km} 2$. Besides, the blue denotes moderate risk, with cases of people without symptoms, while the orange signifies an area with relatively severe conditions, due to people identified through monitoring. The red zone is massive because there are patients under surveillance. Simultaneously, the black is a critical zone because positive cases of Covid-19 have been identified (Task Force of Acceleration of Handling Covid-19, West Java Province, 2020). Based on the village level's zoning system, mothers are expected to have higher maternal awareness while living in the red/black zone compared to those in the green, blue, and orange.

The infographic data on the continuous spread of the Covid-19 virus in Indonesia reported in September stated a total number of 236,519 confirmed sufferers, and 170,774 have been declared cured. The top 5 provinces out of 34 with positive cases consecutively include East Java, DKI Jakarta, South Sulawesi, Central Java, and West Java (Task Force of Acceleration of Handling Covid-19, 2020). 
The data obtained from the task force to accelerate the management show $47.4 \%$ of female sufferers, and $52.6 \%$ male. However, $45.5 \%$ of the women have been cured, much lower than men, at $54.5 \%$. Besides, pregnant women comprise about $4.1 \%$ of the 55,092 sufferers, of which $3 \%$ were declared cured, while $0.4 \%$ died. As many as $0.7 \%$ were being provided with medical care (Task Force of Acceleration of Handling Covid19, 2020).

Based on age classification, Covid-19 affects all groups from 0 to greater than 60 years. The highest proportion of $30.4 \%$ observed at the 31-45 year bracket, followed a frequency of $22.4 \%$ produced by the $18-30$ group (Task Force for the Acceleration of Handling Covid-19, 2020). The outcomes were in harmony with the results of this study. The adaptation response was unaffected by age. The virus was capable of afflicting individuals across all age groups. Meanwhile, the pandemic triggered various changes in societal lifestyle. Hence the novel terminology is no longer considered a new habit but a routine to be implemented henceforth. However, the researchers discovered that different aspects of education levels brought about health-related problems. Similarly, Hoffmann and Lutz (2019) conducted a study to assess individuals' health routines, including exercise, fruit intake, hand washing, water consumption, etc. The results demonstrated the relationships between the knowledge of health and educational ranks. The influence of these positions on Covid-19 awareness was affirmed by Zhong et al. (2020) in the outcomes of the research published in the International Journal of Biological Sciences.

Furthermore, another generally implementable adaptation separate from washing hands and using masks was implementing environmental changes through personal enlightenment about the virus using numerous media. Meanwhile, the swift spread of the pandemic resulted in rapid modifications in maternal health service guidelines, and also highlighted the need for self-awareness, and possession of updated knowledge about Covid-19 (Murphy et al., 2014; Ohannessian, Duong and Odone, 2020)

\section{CONCLUSION}

The mother's most recent educational status influenced the score for the new habitual 
adaptation, while the residence, along with age did not. Also, several tasks including the use of hand sanitizers and masks, the search for information about Covid-19, the maximization of online communication media use, as well as matters related to the general prevention of the disease during pregnancy and childbirth, in postpartum circumstances, and newborns, alongside during family were rarely performed by mothers according to the results. Moreover, the cessation virus transmission in Karawang Regency was not solely focused on educational efforts by health workers, but also self-awareness to regularly maintain personal and environmental hygiene and exert regular efforts towards the prevention of Covid-19.

\section{ACKNOWLEDGMENT}

The members of this research team are grateful to the Karawang Branch of the Indonesian Midwives Association for supporting the entire process and the University of Singaperbangsa Karawang for providing the opportunity to publish this study internationally in an oral presentation.

\section{REFERENCE}

Boelig, R. C. et al. 2020. Labor and delivery guidance for COVID-19. American Journal of Obstetrics \& Gynecology
$M F M, \quad$ p. $\quad 100110 . \quad$ DOI: 10.1016/j.ajogmf.2020.100110.

Cheng, V. C. C. et al. 2020. The role of community-wide wearing of face mask for control of coronavirus disease 2019 (COVID-19) epidemic due to SARSCoV-2. Journal of Infection, 81: 107114. DOI: 10.1016/j.jinf.2020.04.024.

Renfrew, M. J., Cheyne, H., Craig, J., Duff, E., Dykes, F., Hunter, B., Lavender, T., Page, L., Ross-Davie, M., Spiby, H., \& Downe, S. 2020. Sustaining quality midwifery care in a pandemic and beyond. Midwifery, 88: 102759. https://doi.org/10.1016/j.midw.2020.1 02759

Doshi, A. et al. 2020. Keep Calm and Log On: Telemedicine for COVID-19 Pandemic Response. Journal of hospital medicine. DOI: 10.12788/jhm.3419.

Glasper, A. 2020. Healthcare regulators' responses to the COVID-19 pandemic. Br J Nurs, 29(8): 484-485

Task Force of Accelerating of Handling Covid-19. 2020). Infographic Covid19 di Indonesia. Jakarta.

Task Force of Accelerating of Handling Covid-19. 2020. Covid-19 Mapping Indonesia. Jakarta.

Task Force of Accelerating of Handling Covid-19. 2020. Health Risk and Social Economic Activity. Jakarta. Available at: https://covid19.go.id/p/protokol/protok ol-risiko-kasus. 
Task Force of Accelerating of Handling Covid-19 of West Java Province. 2020. Zone Criteria in Subdistrict Level. Bandung: West Java Province Government.

Hill, B. 2020. Coronavirus: Origins, signs, prevention, and management of patients. British Journal of Nursing, 29(7): $\quad 399-402 . \quad$ DOI: 10.12968/bjon.2020.29.7.399.

Hoffmann, R., and Lutz, S. U. 2019. The health knowledge mechanism: evidence on the link between education and health lifestyle in the Philippines. European Journal of Health Economics, 20(1): 27-43. DOI: 10.1007/s10198-017-0950-2.

Jernigan, D. B. 2020. Update: Public health response to the coronavirus disease 2019 outbreak - United States, Feb 24th, 2020. Morbidity and Mortality Weekly Report, 69(8): 216-219. DOI: 10.15585/MMWR.MM6908E1.

Kampf, G. et al. 2020. Persistence of coronaviruses on inanimate surfaces and their inactivation with biocidal agents. Journal of Hospital Infection, 104(3): 246-251. DOI: 10.1016/j.jhin.2020.01.022.

Ministry of Health of Indonesia. 2019. Ministry of Health Regulation of Indonesia No 20 of 2019 about Health Service Providing. pp. 1-15.

Ministry of Health of Indonesia. 2020. Guidance for Pregnant Women, Post Partum, Newborn during Social
Distancing. Jakarta: Kementerian Kesehatan Republik Indonesia.

Liberati, M. et al. 2020. Systematic Review Outcome of coronavirus spectrum infections a systematic review and meta-analysis. The American Journal of Obstetrics \& Gynecology MFM, p. 100107. DOI: 10.1016/j.ajogmf.2020.100107.

Liu Y, Chen H, Tang K, Guo Y. 2020. Clinical manifestations and outcome of SARS-CoV-2 infection during pregnancy. J Infect.

MacIntyre, C. R. et al. 2015. A clusterrandomized trial of cloth masks compared with medical masks in healthcare workers. BMJ Open, 5(4): 1-10. DOI: $10.1136 /$ bmjopen-2014006577.

Murphy, M. M. et al. 2014. Associations of consumption of fruits and vegetables during pregnancy with infant birth weight or small for gestational age births: a systematic review of the literature. International Journal of Women's Health, 6: 899-912. DOI: 10.2147/IJWH.S67130.

Ohannessian, R., Duong, T. A., and Odone, A. 2020. Global Telemedicine Implementation and Integration Within Health Systems to Fight the COVID19 Pandemic: A Call to Action', JMIR Public Health and Surveillance, 6(2): 18810. DOI: 10.2196/18810.

Rasmussen, S. A., and Jamieson, D. J. 2020. Coronavirus disease 2019 (COVID-19) and pregnancy: Responding to a rapidly evolving situation. Obstetrics 
and Gynecology. DOI: 10.1097/AOG.0000000000003873.

Sari, D. K. et al. 2020. Positive Correlation Between General Public Knowledge and Attitudes Regarding COVID-19 Outbreak 1 Month After First Cases Reported in Indonesia. Journal of community health. DOI: 10.1007/s10900-020-00866-0.

Shi, Y., et al. 2020. An overview of COVID-19. Journal of Zhejiang University. Science. B, 21(5): 343360.

https://doi.org/10.1631/jzus.B2000083

Sohrabi, C., et al. 2020. World Health Organization declares global emergency: A review of the 2019 novel coronavirus (COVID19). International journal of surgery (London, England), 76: 71-76. https://doi.org/10.1016/j.ijsu.2020.02.0 34

Ministry of National Affairs. 2020. Covid19 Pandemic Guidance for Local Government: Prevention, Control, Diagnosis, and Management. Journal of Chemical Information and Modeling, 53(9):1689-1699. DOI: 10.1017/CBO9781107415324.004.

WHO et al. 2015. Trends in Maternal Mortality: 1990 to 2015: estimates by WHO, UNICEF, UNFPA, World Bank Group, and the United Nations
Population Division. The organization, pp. 1-38. DOI: 9789241503631.

World Health Organization. 2020. Maintaining essential health services: operational guidance for the COVID19 context. Geneva: World Health Organization.

World Health Organization Indonesia. 2020. Operational Guidance for South East Asia and Asia Pacific. Jakarta: WHO Indonesia.

Worldometer. 2020. Reported Cases and Deaths by Country, Territory, or Conveyance. Available at: https://www.worldometers.info/corona virus/\#countries.

Zhai, P., et al. 2020. The epidemiology, diagnosis, and treatment of COVID19. International journal of antimicrobial agents, 55(5): 105955. https://doi.org/10.1016/j.ijantimicag.20 20.105955

Zhong, B. L. et al. 2020. Knowledge, attitudes, and practices towards COVID-19 among Chinese residents during the rapid rise of the COVID-19 outbreak: A quick online crosssectional survey. International Journal of Biological Sciences, 16(10): 17451752. DOI: $10.7150 / \mathrm{ijbs} .45221$. 